\title{
Population dynamics of spotted wing drosophila (Drosophila suzukii) in orchards in the Zagreb area
}

\author{
Dinamika populacije octene mušice ploda (Drosophila suzukii) u \\ voćnjacima na području Zagreba
}

Ivana Pajač Živković, Irena Brlić Puškarić, Darija Lemić

\begin{abstract}
The invasive species Drosophila suzukii (Matsumura, 1931), the spotted wing drosophila, was first recorded in Croatia in 2010. Since then, it has spread on Croatian territory but its presence has not yet been confirmed in the City of Zagreb. In this research population dynamics of $D$. suzukii was investigated in three orchards in Zagreb (Maksimir, Jelenovac, Zelenjak) in the period from $20^{\text {th }}$ of March to $27^{\text {th }}$ of November 2017. Feeding traps with apple vinegar were used for catching $D$. suzukii. The flight began in the period from $27^{\text {th }}$ of June to $11^{\text {th }}$ of July and lasted until $27^{\text {th }}$ of November. The total pest catches were 874 specimens (Jelenovac 187, Maksimir 232 and Zelenjak 455). From September to November there was a continuous flight and a large increase in the number of caught flies, suggesting the presence of more overlapping generations. Besides the host plants, the development of the pest in this area is also enabled by suitable climatic conditions. The present population in the City of Zagreb County poses a danger to fruit producers in the Zagreb County. The results of this research are a contribution to better understanding of the population and the spread of the pest in Croatia.
\end{abstract}

Key words: catch dynamics, City of Zagreb, Drosophila suzukii, perennial crops

\section{SAŽETAK}

Invazivna vrsta Drosophila suzukii (Matsumura, 1931.), prvi put je zabilježena u Hrvatskoj 2010. godine. Od tada proširila se na području Hrvatske, ali njezina prisutnost još nije potvrđena u gradu Zagrebu. U ovom istraživanju dinamika populacije vrste D. suzukii istraživana je u tri voćnjaka u Zagrebu (Maksimir, Jelenovac, Zelenjak) u razdoblju od 20. ožujka do 27. studenoga 2017. godine. Za praćenje vrste korištene su hranidbene lovke na bazi jabučnog octa. Let štetnika započeo je u razdoblju od 27. lipnja do 11. srpnja i trajao je do 27. studenog 2017. godine. Ukupno su ulovljena 874 primjerka vrste (Jelenovac 187, Maksimir 232 i Zelenjak 455). Od rujna do studenog zabilježen je neprekidni let i velik porast broja ulovljenih muha, što pretpostavlja prisutnost više generacija štetnika na području istraživanja. Osim pogodnih biljaka 
Ivana Pajač Živković i sur.: Population dynamics of spotted wing drosophila (Drosophila suzukii) in orchards in the Zagreb area

domaćina, razvoj šetnika na ovom području omogućen je i povoljnim klimatskim uvjetima. Utvrđena populacija štetnika u gradu Zagrebu predstavlja opasnost za proizvođače voća u Zagrebačkoj županiji. Rezultati istraživanja doprinos su boljem poznavanju populacije i širenju štetnika na području Hrvatske.

Ključne riječi: dinamika ulova, Drosophila suzukii, Grad Zagreb, višegodišnji nasadi

\section{INTRODUCTION}

The spotted wing drosophila, Drosophila suzukii (Matsumura, 1931) is an invasive pest originating in eastern Asia (Asplen et al., 2015) where it was first recorded and described in Japan in 1916 (Asplen et al., 2015). For the last decade it has spread to European, as well as South and North American countries (Zerulla et al., 2015). D. suzukii is polyphagous species; its larvae feed on more than 100 cultivated and wild hosts from more than 25 families (Sampson et al., 2016). This allows successful spread and retention on a large geographic area (Poyet et al., 2015). First record of D. suzukii in Europe was during 2008 in parts of France, Italy and Spain (Baser et al., 2015). In Croatia it was first recorded in 2010 (Masten Milek et al., 2011). The key to its great invasion is the ability to adapt to various climatic conditions and wide range of hosts, having large number of overlapping generations, limited number of natural enemies and high female fertility (Cini et al., 2014; Zerulla et al., 2015; Klick et al., 2016). So far, economic damages in Europe have been recorded in Italy, France, Spain (Asplen et al., 2015), Switzerland (Mazzi et al, 2017) and in Croatia (Pajač Živković et al., 2016). The wide and fast spread has been enabled by the global trade in fruit and plant material (Klick et al., 2016).

The development from egg to adult lasts 8 to 14 days and as adult forms they are able to live for 3 to 9 weeks, forming up to 13 generations per year (Calabria et al., 2012). Females lay eggs on stone and soft fruits with their sclerotized ovipositor (Sampson et al. 2016); after developing from eggs inside fruits, feeding larvae cause fruit decay (Pajač \& Barić, 2010). During one oviposition, the female can lay up to 3 eggs (Masten Milek et al., 2013). Inside one fruit there can be eggs from more than one female (Masten Milek et al., 2013), but the overall number of developing larvae is set by the size of the fruit (Poyet et al., 2015). Oviposition is mainly happening in the phase of fruit color change (Lee et al., 2011). Females visually locate the host using color contrast; green versus red and blue versus yellow (Little et al., 2019). Damage is done by larvae feeding inside fruit causing the fruit to become soft to the touch, mesocarp changes color and the location of the sting is subject to the attack of 
Ivana Pajač Živković i sur.: Population dynamics of spotted wing drosophila (Drosophila suzukii) in orchards in the Zagreb area

secondary pests and pathogens (Pajač \& Barić, 2010). Such fruit is reduced in quality, unsuitable for consumption in fresh state and for industrial processing (Zerulla et al., 2015).

Although a complete protection plan has not yet been developed (Masten Milek et al., 2015), it is assumed that insecticide treatments would be effective at the time of fruit ripening (Walsh et al., 2011), that is, when the fruit changes color (Kleiber et al., 2014). Recent reaserch has shown that D. suzukii is more attracted to traps made of mixture of red wine and apple cider vinegar, especially in mass trapping (Marjanović \& Tanasković, 2019). Methods using natural enimies have not had much effect so far; D. suzukii appears to react differently with parasites and parasitoids depending on the environmental conditions of the area in which it is located (Bohinc \& Trdan, 2014). Also, it has been proven that $D$. suzukii detects and avoids the parasitoid wasp Leptopilina boulardi by sensing its pheromone compounds (Ebrahim et al., 2015). Research in the UK has shown efficacy of spinosad at all stages of $D$. suzukii, even on the larvae inside the fruit (Cuthbertson et al., 2014).

The presence and flight dynamics of $D$. suzukii have not yet been studied for the City of Zagreb. Such research would have an impact on better knowledge of the population and the spread of the pest in orchards in this area. It is assumed that $D$. suzukii is already present in this area due to its presence in neighboring counties and also because of favorable climatic conditions and wide range of hosts. The assumption is that the pest develops several overlapping generations in the mentioned area. Furthermore, the presence of $D$. suzukii in the city can lead to loses in extensive fruit production, but could also make Zagreb a focal point for further spread on intensive orchards existing in the area of Zagreb County.

\section{MATERIALS AND METHODS}

The monitoring of $D$. suzukii population dynamics was carried out during the vegetative season of 2017 in three orchards in Zagreb: Jelenovac $\left(45^{\circ} 49^{\prime} 28^{\prime \prime} \mathrm{N}, 15^{\circ} 57^{\prime} 28^{\prime \prime} \mathrm{E}\right)$, Maksimir $\left(45^{\circ} 49^{\prime} 43^{\prime \prime N}, 16^{\circ} 01^{\prime} 44^{\prime \prime} \mathrm{E}\right)$ and Zelenjak (45⒋'11"N, 1559'37"E).

Orchards Jelenovac and Zelenjak are extensive orchards on private property and the orchard Maksimir is one of the experiment stations of the University of Zagreb, Faculty of Agriculture. In all three orchards there are several species of stone, soft and pome fruits. In Jelenovac there are plums, apricots, cherries, apples, pears, red currants, blackberries, and raspberries. This orchard is located near the forest park Jelenovac, a mixed forest of oak, beech, hornbeam, and acacia (Zg Portal, 2013). 
For the insight into the meteorological conditions in Zagreb, data of the Croatian Meteorological and Hydrological Service for 2017 were used (DHMZ, 2018). For this study, data referring to the mean monthly air temperatures and total monthly precipitation rates from the nearest meteorological station Maksimir were processed (Table 1). The lowest average monthly air temperature was recorded in January $\left(-3.2^{\circ} \mathrm{C}\right)$ and the highest in July $\left(24^{\circ} \mathrm{C}\right)$. During the year 2017, the average annual air temperature amounted to $12.6{ }^{\circ} \mathrm{C}$ while the total annual precipitation amounted to $897 \mathrm{~mm}$. The lowest total monthly precipitation amounted to $19.8 \mathrm{~mm}$ and was recorded in March, while the highest was recorded in September amounting to $239.6 \mathrm{~mm}$.

Table 1 Mean monthly air temperature $\left({ }^{\circ} \mathrm{C}\right)$ and total monthly precipitation $(\mathrm{mm})$ for City of Zagreb in 2017.

Tablica 1. Prikaz srednjih mjesečnih temperatura zraka $\left({ }^{\circ} \mathrm{C}\right)$ i ukupnih mjesečnih oborina $(\mathrm{mm})$ na području Grada Zagreba u 2017. godini.

\begin{tabular}{|l|c|c|c|c|c|c|c|c|c|c|c|c|c|}
\hline \multicolumn{1}{|c|}{ 2017. } & I & II & III & IV & $\mathbf{V}$ & VI & VII & VIII & IX & $\mathbf{X}$ & $\mathbf{X I}$ & $\mathbf{X I I}$ & $\begin{array}{c}\text { Mean annual } \\
\text { air temp. } \\
\left({ }^{\circ} \mathrm{C}\right)\end{array}$ \\
\hline $\begin{array}{l}\text { Mean } \\
\text { monthly air } \\
\text { temp. }\left({ }^{\circ} \mathrm{C}\right)\end{array}$ & -3.2 & 5.2 & 10.0 & 12.4 & 17.7 & 22.5 & 24.0 & 23.7 & 15.4 & 11.9 & 7.3 & 4.0 & 12.6 \\
\hline $\mathbf{2 0 1 7}$. & $\mathbf{I}$ & $\mathbf{I I}$ & $\mathbf{I I I}$ & $\mathbf{I V}$ & $\mathbf{V}$ & $\mathbf{V I}$ & $\mathbf{V I I}$ & $\mathbf{I I I}$ & $\mathbf{I X}$ & $\mathbf{X}$ & $\mathbf{X I}$ & $\mathbf{X I I}$ & $\begin{array}{c}\text { Total annual } \\
\text { precipitation } \\
\text { (mm) }\end{array}$ \\
\hline $\begin{array}{l}\text { Total } \\
\text { monthly } \\
\text { precipitation } \\
\text { (mm) }\end{array}$ & 34.3 & 41.4 & 19.8 & 44.3 & 35.2 & 107.8 & 58.0 & 39.1 & 239.6 & 72.0 & 113.2 & 92.3 & 897.0 \\
\hline
\end{tabular}

The flies were sampled by using feeding traps made from plastic bottles of $500 \mathrm{ml}$ volume filled with apple vinegar. In each orchard one feeding trap was set on $30^{\text {th }}$ of March 2017 and samples were collected every 15 days. The species population monitoring lasted until $27^{\text {th }}$ of November 2017. During the monitoring period, a total of 54 samples of flies was collected. The collected samples were stored in $70 \%$ alcohol. Determination of the samples was performed in the entomological laboratory of the Department for Agricultural Zoology by using the binocular stereo microscope and following the OEPP / EPPO Diagnostic Protocol PM 7/115 (1) for D. suzukii type (OEPP / EPPO, 2013). 
Ivana Pajač Živković i sur.: Population dynamics of spotted wing drosophila (Drosophila suzukii) in orchards in the Zagreb area

\section{RESULTS AND DISCUSSION}

The presence of $D$. suzukii flies was found in all three explored orchards. Altogether 874 individuals were caught, out of which 421 were males $(48 \%$ of the total catch) and 453 were females (52\% of the total catch). Since the proportion of males and females in the population should be the same, the predominant share of females is a prerequisite for a successful population expansion and the spread of flies in a given area (Kovačević, 1959).

As shown in Figure 1., the highest catch was recorded in the orchard Zelenjak where 455 flies (52\%) were caught ( 233 males and 222 females). First flies were caught between $11^{\text {th }}$ and $24^{\text {th }}$ of July. The flight increased slightly during August and September, and in October it increased rapidly. Number of caught females during that period (52 individuals) was lower in comparison to males (83 individuals). By the end of the monitoring period, i.e. until $27^{\text {th }}$ of November, the maximum number of individuals (140 males and 164 females) was recorded. The orchard Zelenjak had the highest number of present flies probably because of the widest range of fruit tree hosts which were grown there.

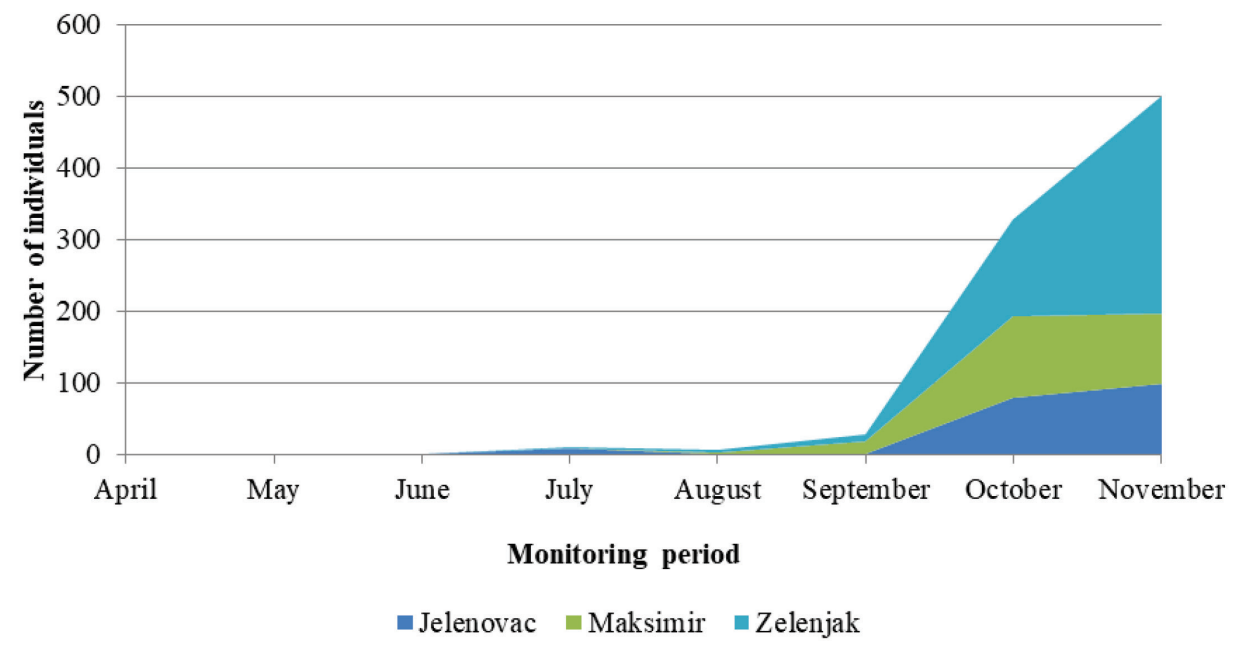

Figure 1 Relation between numbers of Drosophila suzukii caught in three orchards during monitoring period in 2017 in the Zagreb area.

Slika 1. Odnos između brojnosti vrste Drosophila suzukii ulovljene u tri voćnjaka tijekom perioda praćenja u 2017. godini na području Zagreba. 
Ivana Pajač Živković i sur.: Population dynamics of spotted wing drosophila (Drosophila suzukii) in orchards in the Zagreb area

Second to the highest catch was recorded in the orchard Maksimir with 232 caught flies (27\%) (99 males and 133 females) (Figure 1). The flight started in the period from $8^{\text {th }}$ to $21^{\text {st }}$ of August. By the end of the monitoring period, the number of males increased in October and November. Female catch dynamics peaked during October, and began to decline during November.

The lowest catch was recorded in the orchard Jelenovac where 187 flies were caught (21\%) (89 males and 98 females) (Figure 1). The flight began in the period from $27^{\text {th }}$ of June to $11^{\text {th }}$ of July. The first period of flight lasted until middle of August. A re-catch was recorded in October, from when the flight lasted until the end of the monitoring period (until $27^{\text {th }}$ of November). In the last monitoring period, a maximum number of adult specimens of the species (99 individuals; 40 males and 59 females) was caught. In this orchard the decrease in the number of caught males was observed in the period from July to August. Also, from October until the end of the monitoring period the males' catch in relation to the females' was lower. Several more female flies (98 individuals) were caught in comparison to male flies (89 individuals).

In all three researched orchards an increase in caught $D$. suzukii flies by the end of monitoring period (October and November) was observed (Figure 1). The population began to increase in September and a sharp increase in catches was recorded during October when more males were caught in relation to females. The trend of catches continued in November. Depending on sex and date of captured individuals, it is assumed that males started to fly two weeks before females, but a greater number of females were active until the end of November or in colder days. This diference corresponds to the literature data on the increased number of overwintering females (Zerulla et al., 2015).

The pest was sporadically present at the beginning of the monitoring period which is why it is assumed thet D. suzukii individuals did not overwinter in these three orchards and were attracted by apple vinegar traps. The increase in later period (mid-September) was probably due to mixed fruit varieties at different stages of ripening which also had an impact on population maintenance and growth until the end of monitoring period. This pattern with low capture period during summer has also been observed in Italy, Switzerland, Germany, Spain, Belgium and in the United States (Clymans et al., 2019). Females have host preferences troughout the year and primarily are in search of oviposition sites, unlike the winter females, which are in search of overwintering sites and are much more attracted by fermentaton compounds in traps (Clymans et al., 2019). Trap counts only start increasing in late summer, to reach peak levels in autumn (Clymans et al., 2019). 
Ivana Pajač Živković i sur.: Population dynamics of spotted wing drosophila (Drosophila suzukii) in orchards in the Zagreb area

The survival and population maintenance of $D$. suzukii is not only limited by hosting plants but also by meteorological coditions such as average annual air temperature, minimum air temperature and annual precipitation (dos Santos et al., 2017).

These flies require an average annual air temperature of 5 to $20^{\circ} \mathrm{C}$ (dos Santos et al., 2017) and for active flight minimum air temperature of $10^{\circ} \mathrm{C}$ (Asplen et al., 2015). According to DHMZ (2018), average annual air temperature for Zagreb in 2017 amounted to $12.6^{\circ} \mathrm{C}$. The average daily air temperature required for $D$. suzukii flight is $10^{\circ} \mathrm{C}$ and was achieved throughout the day in July, August and September, whereas in October it fell below $10^{\circ} \mathrm{C}$ for 6 days and in November for 19 days (Figure 2). Those other days in October and November when the air temperature was over $10^{\circ} \mathrm{C}$ allowed D. suzukii to keep on searching for a source of food and place for overwintering.

An annual precipition that favors survival of $D$. suzukii in given area is between 500 and $2500 \mathrm{~mm}$ (dos Santos et al., 2017). An annual rainfall in Zagreb area in 2017 was $897 \mathrm{~mm}$ which is suitable for the D. suzukii developement (Table 1). The highest monthly precipitation was recorded in September $(239.6 \mathrm{~mm})$, when 28 adult individuals were caught. In November, when the highest number of individuals (501 individuals) was caught, the average monthly precipitation amounted to $113.2 \mathrm{~mm}$ (Figure 2).

The later appearance of adult flies, although the temperature conditions and precipitation rates were suitable throughout most of the monitoring period, is probably the result of later fruit ripening; in the first monitoring period there was no suitable substrate for females to lay their eggs in. Despite low temperatures, the maximum catch was recorded during the last monitoring period. It is assumed that in these last two months flight occurred durring those days when mean daily temperatures were $10^{\circ} \mathrm{C}$ or higher; in October there was a total of 25 such days, and in November 11 days (Figure 2). Also, as there were no rippening fruits available during that last period, the apple vinegar traps were the last source of food before the overwintering. 
Ivana Pajač Živković i sur.: Population dynamics of spotted wing drosophila (Drosophila suzukii) in orchards in the Zagreb area

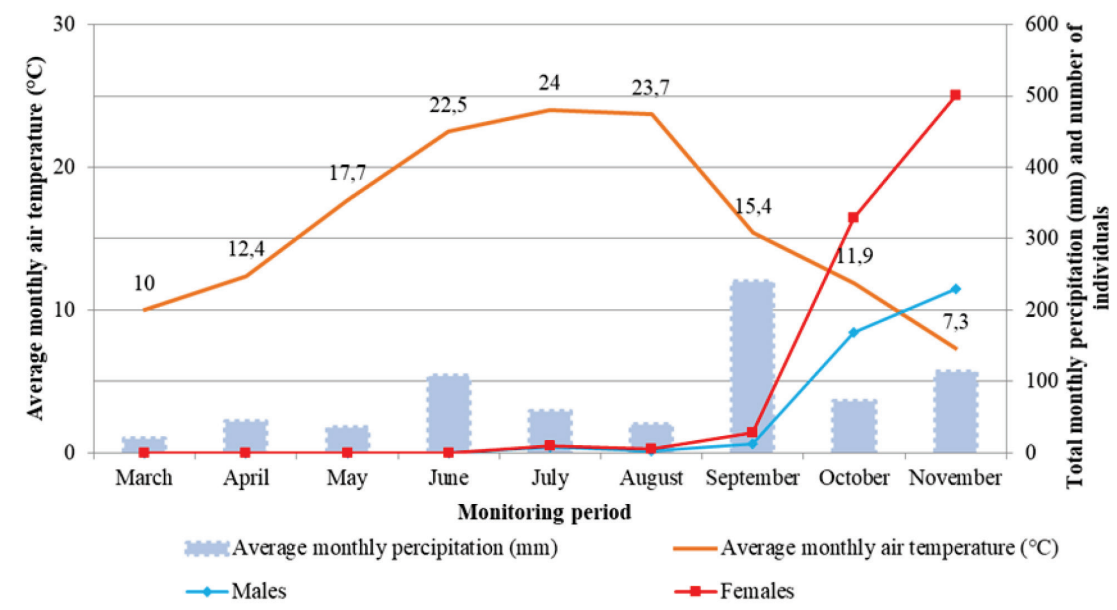

Figure 2 Relation between the total number of Drosophila suzukii and climatic conditions during the monitoring period in 2017 in the orchards of the City of Zagreb.

Slika 2. Odnos ukupnog broja vrste Drosophila suzukii i klimatskih uvjeta tijekom razdoblja praćenja u 2017. godini u voćnjacima na području Zagreba.

Considering the catch dynamics results of D. suzukii in Zagreb's orchards and the decrease in total male catches during October in the Jelenovac and Maksimir orchards, it is assumed that D. suzukii develops several generations per year which, with favorable climatic conditions, overlap each other.

\section{CONCLUSION}

The research on the catch dynamics of D. suzukii populations confirmed presence of D. suzukii in Zagreb area. Since 874 specimens of D. suzukii were found in three orchards, out of which $52 \%$ were females and $48 \%$ were males, the population of this pest has a potential of further spread. Also, climatic conditions in the researched area favor the development of $D$. suzukii, enabling flies to develop several generations per year that overlap. Private yards and surrounding forest vegetation in the City of Zagreb offer food sources and shelter for this pest which makes Zagreb a potential focal point for further spread to industrial orchards in the Zagreb County, especially because there is still no designed protection program for the territory of the Republic of Croatia which would include owners of small private city orchards. 
Ivana Pajač Živković i sur.: Population dynamics of spotted wing drosophila (Drosophila suzukii) in orchards in the Zagreb area

\section{LITERATURE}

ASPLEN, M.K., ANFORA, G., BIONDI, A., CHOI, D., CHU, D., DAANE, K.M., GIBERT, P., GUTIERREZ, A.P. , HOELMER, K.A., HUTCHISON, W.D., ISAACS, R., JIANG, Z., ZSOLT KÁRPÁTI, Z., KIMURA, M.T., PASCUAL, M., PHILIPS, C.R., PLANTAMP, C., PONTI, L., VÉTEK, G., VOGT, H., WALTON, V.M., YU, Y., ZAPPALÀ, L., DESNEUX, N. (2015): Invasion biology of spotted wing Drosophila (Drosophila suzukii): a global perspective and future priorities. Journal of Pest Science. 88(3): 469494. https://doi.org/10.1007/s10340-015-0681-z

BASER, N., OUANTAR, M., BROUTOU, O., LAMAJ, F., VERRASTRO, V., PORCELLI, F. (2015): First finding of Drosophila suzukii (Matsumura) (Diptera: Drosophilidae) in Apulia, Italy, and its population dynamics throughout the year. Fruits. 70(4): 225-230.

https://doi.org/10.1051/fruits/2015016

BOHINC, T., TRDAN, S. (2014): Zatiranje plodove vinske mušice (Drosophila suzukii [Matsumura], Diptera, Drosophilidae) s poudarkom na okoljsko sprejemljivih načinih. Acta agriculturae Slovenica. 103(2): 323-329.

CALABRIA, G., MÁCA, J., BÄCHLI, G., SERRA, L., PASCUAL, M. (2012): First records of the potential pest species Drosophila suzukii (Diptera: Drosophilidae) in Europe. Journal of Applied Entomology. 136: 139-147. https://doi.org/10.1111/j.1439-0418.2010.01583.x

CINI, A., ANFORA, G., ESCUDERO-COLOMAR, L.A., GRASSI, A., SANTOSUOSSO, U., SELJAK, G., PAPINI, A. (2014): Tracking the invasion of the alien fruit pest Drosophila suzukii in Europe. Journal of Pest Science. 87: 559-566. https://doi.org/10.1007/s10340-014-0617-z

CLYMANS, R., VAN KERCKVOORDE, V., BANGELS, E., AKKERMANS, W., ALHMEDI, A., DE CLERCQ, P., BELIËN, T., BYLEMANS, D. (2019): Olfactory Preference of Drosophila suzukii Shifts between Fruit and Fermentation Cues over the Season: Effects of Physiological Status. Insects. 10(7): 1-21. https://doi.org/10.3390/insects 10070200

CUTHBERTSON, A.G.S., COLLINS, D.A., BLACKBURN, L.F., AUDSLEY, N., BELL, H.A. (2014): Preliminary screening of potential control products against Drosophila suzukii. Insects. 5: 488-498.

https://doi.org/10.3390/insects5020488 
DOS SANTOS, L.A., MENDES, M.F., KRÜGER, A.P., BLAUTH, M.L., GOTTSCHALK, M.S., GARCIA, F.R.M. (2017): Global potential distribution of Drosophila suzukii (Diptera, Drosophilidae). PLoS ONE. 12(3): 1-13. https://doi.org/10.1371/journal.pone.0174318

DHMZ (2018): Državni hidrometeorološki zavod. Godišnje izvješće 2017. http://klima.hr/razno/publikacije/godisnje_izvjesce2017.pdf. Accessed $2^{\text {nd }}$ May 2018.

EBRAHIM, S.A.M., DWECK, H.K.M., STÖKL, J., HOFFERBERTH, J.E., TRONA, F., WENIGER, K., RYBAK, J., SEKI, Y., STENSMYR, M.C., SACHSE, S., HANSSON, B.S., KNADEN M. (2015): Drosophila avoids parasitoids by sensing their semiochemicals via a dedicated olfactory circuit. PLoS Biology. 13(12): e1002318.

https://doi.org/10.1371/journal.pbio.1002318

KLEIBER, J.R., UNELIUS, C.R., LEE, J.C., SUCKLING, D.M., QIAN, M.C., BRUCK, D.J. (2014): Attractiveness of fermentation and related products to spotted wing Drosophila (Diptera: Drosophilidae). Environmental Entomology. 43(2): 439-447. https://doi.org/10.1603/EN13224

KLICK, J., YANG, W.Q., WALTON, V.M., DALTON, D.T., HAGLER, J. R., DREVES, A. J., LEE, J. C., BRUCK, D.J. (2016): Distribution and activity of Drosophila suzukii in cultivated raspberry and surrounding vegetation. Journal of Applied Entomology. 140: 37-46.

https://doi.org/10.1111/jen.12234

LEE, J.C., BRUCK, D.J., CURRY, H., EDWARDS, D., HAVILAND, D.R., VAN STEENWYK, R.A., YORGEY, B.M. (2011): The susceptibility of small fruits and cherries to the spotted-wing drosophila, Drosophila suzukii. Pest Management Science. 67: 1358-1367. https://doi.org/10.1002/ps.2225

LITTLE, C.M., RIZZATO, A.R., CHARBONNEAU, L., CHAPMAN, T., HILLIER, N.K. (2019): Color preference of the spotted wing Drosophila, Drosophila suzukii. $\quad$ Scientific $\quad$ Reports. 9: 16051. https://doi.org/10.1038/s41598-019-52425-w

MARJANOVIĆ, M., TANASKOVIĆ, S. (2019): Efficiency of different types of traps in mass trapping Drosophila suzukii (Diptera, Drosophilidae) in raspberry plantings. Acta Agriculturae Serbica. 24(47): 71-81. https://doi.org/10.5937/AASer1947071M 
MASTEN MILEK, T., SELJAK, G., ŠIMALA, M., BJELIŠ M. (2011): PRVI nalaz Drosophila suzukii (Matsumura, 1931) (Diptera: Drosophilidae) u Hrvatskoj. Glasilo biljne zaštite. 11(5): 377-382.

MASTEN MILEK, T., ŠIMALA, M., PAVUNIĆ MILJANOVIĆ, Z. (2013): Octena mušica ploda - Drosophila suzukii (Matsumura, 1931). Hrvatski centar za poljoprivredu, hranu i selo. Zavod za Zaštitu bilja, Zagreb, pp. 22.

MASTEN MILEK, T., ŠIMALA, M., BJELIŠ, M. (2015): Octena mušica ploda (Drosophila suzukii) - štetnik plodova voća. Glasilo biljne zaštite. 15(5): 323327.

MAZZI, D., BRAVIN, E., MERANER, M., FINGER, R., KUSKE, S. (2017). Economic Impact of the Introduction and Establishment of Drosophila suzukii on Sweet Cherry Production in Switzerland. Insects. 8(18): 1-13. https://doi.org/10.3390/insects 8010018

OEPP/EPPO (2013): PM 7/115 (1) Drosophila suzukii. Bulletin OEPP/EPPO. 43(3): 417-424.

PAJAČ, I., BARIĆ B. (2010): Drosophila suzukii (Matsumura, 1931) potencijalni štetnik koštićavog voća u Hrvatskoj. Pomologia Croatica. 16(12): 43-50.

PAJAČ ŽIVKOVIĆ, I., BARIĆ, B., LEMIĆ, D., BLAŽEVIĆ, I., ŠUBIĆ, M., SELJAK, G., MEŠIĆ, A. (2016): The Drosophilid Fauna (Diptera, Drosophilidae) of IPM Vineyards in Croatia. Agriculturae Conspectus Scientificus. 81(4): 231-234.

POYET, M., LE ROUX, V., GIBERT, P., MEIRLAND, A., PRÉVOST, G., ESLIN, P., CHABRERIE, O. (2015): The Wide Potential Trophic Niche of the Asiatic Fruit Fly Drosophila suzukii: The Key of Its Invasion Successin Temperate Europe? PloS ONE. 10(11): 1-26. https://doi.org/10.1371/journal.pone.0142785

SAMPSON, B.J., MALLETTE, T., ADDESSO, K., LIBURD, O.E., IGLESIAS, L.E., STRINGER, S.J., WERLE, C.T., SHAW, D.A., LARSEN, D., ADAMCZYK, JR.J.J. (2016): Novel aspects of Drosophila suzukii (Diptera: Drosophilidae) biology and an improved method for culturing this invasive species with a modified D. melanogaster diet. Florida Entomologist. 99(4): 774-780. https://doi.org/10.1653/024.099.0433 
WALSH, D.B., BOLDA, M.P., GOODHUE, R.E., DREVES, A.J., LEE, J., BRUCK, D.J., WALTON, V.M., O’NEAL, S.D., ZALOM, F.G. (2011): Drosophila suzukii (Diptera: Drosophilidae): Invasive pest of ripening soft fruit expanding its geographic range and damage potential. Journal of Integrated Pest Management. 2(1): G1-G7. https://doi.org/10.1603/IPM10010

ZERULLA, F.N., SCHMIDT, S., STREITBERGER, M., ZEBITZ, C.P.W., ZELGER, R. (2015): On the overwintering ability of Drosophila suzukii in South Tyrol. Journal of Berry Research. 5(1): 41-48.

ZG PORTAL (2013): Zg Portal Zagreb Danas. http://www.zgportal.com/ozagrebu/povijest-zagrebackih-naselja/jelenovac/ Accessed $2^{\text {nd }}$ May 2018.

\section{Authors address - Adresa autora:}

Ivana Pajač Živković, e-mail: ipajac@agr.hr

Irena Brlić Puškarić, student of Graduate study Phytomedicine

Darija Lemić,

University of Zagreb Faculty of Agriculture,

Department of Agricultural Zoology,

Svetošimunska cesta 25, 10000 Zagreb 